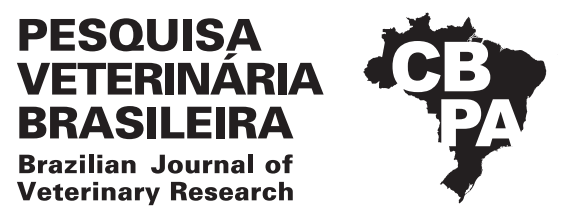

Pesq. Vet. Bras. 38(11):2092-2098, novembro 2018 DOI: 10.1590/1678-5150-PVB-5976

Original Article

Animais de Produção/Livestock Diseases

ISSN 0100-736X (Print)

ISSN 1678-5150 (Online)

\title{
Tuberculosis of the central nervous system in cattle in Paraíba, Brazil ${ }^{1}$
}

\author{
Aline M. Silveira ${ }^{2 *}$, Eduardo M. Nascimento ${ }^{2}$, Guilherme Konradt ${ }^{3}$, \\ Eldinê G. Miranda Neto², David Driemeier³ ${ }^{3}$ Glauco José N. Galiza², \\ Antonio F.M. Dantas ${ }^{2}$ and Franklin Riet-Correa ${ }^{2,4}$
}

\begin{abstract}
Silveira A.M., Nascimento E.M., Konradt G., Miranda Neto E.G., Driemeier D., Galiza G.J.N., Dantas A.F.M. \& Riet-Correa F. 2018. Tuberculosis of the central nervous system in cattle in Paraíba, Brazil. Pesquisa Veterinária Brasileira 38(11):2092-2098. Laboratório de Patologia Animal, Hospital Veterinário, Universidade Federal de Campina Grande, Avenida Universitária s/n, Santa Cecília, Patos, PB 58700-970, Brazil. E-mail: silveira.a.monteiro@ gmail.com

This paper describes six cases of tuberculosis in the central nervous system (CNS) of cattle in the state of Paraíba in northeastern Brazil. We reviewed the autopsy reports of 851 bovine necropsies performed from 2003 to 2016. Seventy-three (8.6\%) cattle were diagnosed with tuberculosis and six showed lesions in the CNS. Three cases affected cattle up to two-year-old and other three affected adults. Three cattle presented exclusively nervous signs, two had respiratory signs and weight loss and one did not present any clinical signs. At necropsy, five cattle had thickening of the leptomeninges of the cerebellum, pons, obex, spinal cord and cortex, mainly, in the region near the brain basilar Willis' circle. Another animal, presented a single focal lesion in the cerebellum. Microscopically we observed moderate to severe granulomatous meningitis and encephalitis. Five cattle presented lesions in the lungs and mediastinal lymph nodes and three of them had disseminated lesions in other organs. In all cattle acid-fast bacilli were observed in the lesions and marked positive for immunohistochemistry with polyclonal antibody anti-Mycobacterium tuberculosis. It is concluded that bovine tuberculosis of central nervous system occurs sporadically in Paraíba, in cattle of different ages, most of them with disseminate lesions in other organs. The location of the lesions suggests that the agent invaded the brain by hematogenous route through the circle of Willis.
\end{abstract}

INDEX TERMS: Tuberculosis, central nervous system, cattle, Paraíba, Brazil, Mycobacterium sp., acid-fast resistant bacteria, Ziehl Neelsen, pathology, bacterioses.

RESUMO.- [Tuberculose no sistema nervoso central de bovinos na Paraíba.] Descrevem-se seis casos de tuberculose no sistema nervoso central (SNC) em bovinos, no semiárido da Paraíba. Foram revisados os laudos de um total de 851 necropsias de bovinos realizadas no período de 2003 a 2016. Destes,

\footnotetext{
${ }^{1}$ Received on June 26, 2018.

Accepted for publication on July 12, 2018.

${ }^{2}$ Programa de Pós-Graduação em Medicina Veterinária, Universidade Federal de Campina Grande (UFCG), Av. Universitária s/n, Bairro Santa Cecília, Patos, PB 58708-110, Brazil. * Corresponding author: silveira.a.monteiro@gmail.com

${ }^{3}$ Setor de Patologia Veterinária, Hospital Veterinário, Universidade Federal do Rio Grande do Sul (UFRGS), Av. Bento Gonçalves 9090, Agronomia, Porto Alegre, RS 90540-000, Brazil.

${ }^{4}$ Instituto Nacional de Investigación Agropecuaria (INIA), Estación Experimental INIA La Estanzuela, Ruta $50 \mathrm{Km}$ 11, Colonia del Sacramento, Colonia, Uruguay. E-mail: frcorrea@inia.org.uy
}

$73(8,6 \%)$ foram diagnosticados com tuberculose e seis apresentavam lesões no SNC. Três casos ocorreram em bovinos de até dois anos de idade e três em bovinos adultos. Três bovinos apresentaram exclusivamente sinais nervosos, dois tinham sinais respiratórios e perda de peso e um não apresentava nenhum sinal clínico. Macroscopicamente, em cinco bovinos, havia espessamento das leptomeninges do cerebelo, medula espinhal, ponte, obex, colículos e córtex, principalmente, na região basilar encefálica próxima ao polígono de Willis. Em apenas um bovino houve a presença de tubérculo único no cerebelo. Microscopicamente observou-se moderada a acentuada meningite e encefalite granulomatosa. Cinco bovinos apresentaram lesões pulmonares e nos gânglios mediastínicos e três deles tinham lesões disseminadas em outros órgãos. Em todos os bovinos foram encontrados bacilos ácido-álcool resistentes intralesionais e todos tiveram marcação 
positiva na técnica de imuno-histoquímica com anticorpo policlonal anti-Mycobacterium tuberculosis. Conclui-se que a tuberculose do sistema nervoso central de bovinos ocorre de forma esporádica na Paraíba, principalmente em bovinos com lesões disseminadas em outros órgãos. Sugere-se que a disseminação do agente ocorre pela via hematógena, possivelmente através do polígono de Willis.

TERMOS DE INDEXAÇÃO: Tuberculose, sistema nervoso central, bovinos, Paraíba, Mycobacterium sp., bactérias ácido-álcool resistentes, Ziehl Neelsen, patologia, bacterioses.

\section{INTRODUCTION}

Tuberculosis is an important disease for the Brazilian farming and public health. It causes economic loss because of the low production of milk and meat and by the slaughter of the animals positive to the intradermal allergic test, implanted by the Brucellosis and Tuberculosis Control and Eradication National Program (Programa Nacional de Controle e Erradicação da Tuberculose e da Brucelose - PNCETB). Besides, the direct contact of the workers with the bovines and infected foods implicates in the possibility of infection of the human beings by Mycobacterium spp. (Roxo 1997, Riet-Correa \& Garcia 2007).

Commonly, the bovine affected by the disease present progressive weight loss, and in some cases unproductive cough; these signs are associated to the aerial transmission way (Andreazza et al. 2015). Sporadically, young bovines present clinical neurological manifestation and granulomatous lesions in the leptomeninges of the encephalon and spinal cord (Oruç 2005, Riet-Correa \& Garcia 2007, Del Fava et al. 2010). The lesions location in these cases is related to the transplacental transmission way or infection through ingestion of contaminated milk, being the dissemination through hematogenous way, which enables the ascendance to the central nervous system (CNS) (Roxo 1997, Oruç 2005, Riet-Correa \& Garcia 2007, Del Fava et al. 2010, Borges et al. 2013, Domingo et al. 2014).

In Brazil there are few studies reporting the infection by Mycobacterium spp. affecting the CNS of bovine and mostly they report the infection in sporadic or isolated cases (Galiza et al. 2010, Konradt et al. 2016). This study aims the description of epidemiological, clinic-pathological, and histological findings of six tuberculosis cases in the CNS in bovine.

\section{MATERIALS AND METHODS}

Tuberculosis cases with CNS involvement were researched among bovine necropsy reports found in the archives of the Animal Pathology Laboratory of the Campina Grande Federal University (Laboratório de Patologia Animal da Universidade Federal de Campina Grande (LPA-UFCG), in a 14-year period (2003-2016). Of these reports, information about breed, gender and age, clinical signs, tuberculin test, and the macroscopic and histological alterations previously described were taken. Specimens of CNS and other organs from necropsies had been fixed in 10\% formaldehyde and routinely processed for histopathology. Sections of 3-5 $\mu$ m, stained with the hematoxylin and eosin (HE) technique, were evaluated to characterize the inflammatory response in each case. In CNS sections, histochemical techniques such as Ziehl-Neelsen, Masson's Trichrome and Von Kossa were also performed for visualization of the agent, fibrous connective tissue and mineralization disclosure, respectively. CNS sections were selected to the immuno-histochemical exam, in which the anti-Mycobacterium tuberculosis polyclonal antibody in the dilution 1:200 in PBS were used (phosphate-buffered saline). To block the endogenous peroxidase, $10 \%$ hydrogen peroxide was used for 15 minutes. The antigenic recovery was performed with XIV protease for 15 minutes in ambience temperature. The block of the nonspecific reactions was performed with casein solution (skim powdered milk) at 5\% for 15 minutes in ambience temperature. The primary antibody was incubated for 45 minutes at $37^{\circ} \mathrm{C}$. The secondary antibody biotinylated and the streptavidin-biotin-peroxidase complex (LSAB+System-HRP) were used consecutively, incubated in ambience temperature for 20 minutes each. $\mathrm{EC}^{3}$ (3-Amino-9-ethylcarbazole) was the chromogen used, and after this process the sections were stained with Harri's hematoxylin for one minute, dehydrated and mounted with aqueous medium and cover slip. For positive control, a bovine lung fragment with Mycobacterium bovis positive diagnosis in the PCR technique was used (polymerase chain reaction). As negative controls, the same tested sections were used, with substitution of the primary antibody by antibody diluent.

\section{RESULTS}

From 851 bovine necropsies performed in the LPA-UFCG from 2003 to 2016, 73 (8.58\%) had positive diagnosis for tuberculosis, and in six cases (8.2\%) there was CNS involvement.

All six bovines with CNS lesion were from dairy farms with semi-extensive breeding regime. The epidemiological data, the six bovine's clinical signs, and the results of the tuberculin test performed in two animals are described in Table 1. Only Bovine 1 and 6 were necropsied with previous suspect of tuberculosis. In all other cases the presumptive diagnosis of tuberculosis was not considered, and Bovine 4 and 5 had clinical suspicion of rabies. Case 3 did not present clinical signs and euthanasia was performed due to the positivity of the brucellosis test. In Bovine 2 the suspicion of tuberculosis happened after accentuated lymphocytosis verification in the cerebrospinal fluid analysis.

The tuberculin test was performed in Bovine 1, which reacted positively to the test, and in Bovine 2 which was negative. The tuberculin test was not performed in the other animals. Bovine 1 and 2 died spontaneously due to the aggravation of their clinical condition. Bovine 4 and 5 were euthanized due to the severity of their neurological clinical signs.

Macroscopically, leptomeninges of the brain stem ventral region of Bovine 1, 2, 3 and 5 were observed gray and moderately thickened (Fig.1A) by many nodules of $0.2-1 \mathrm{~mm}$ of diameter, yellowish and irregular with consistency varying from soft to hard. The meninges thickening involved the colliculi and extended until the leptomeninges of the sacral spinal cord in Bovine 2 and 5 (Fig.1B), and it affected the leptomeninges of the frontal cortex, falx cerebri, tentorium cerebelli, and cerebellum in Bovine 3. There was a minor cerebellar herniation in Bovine 4 associated to the yellow-whitish, rough, soft mass, with approximately $3 \mathrm{~cm}$ of diameter in the fourth ventricle region (Fig.1C). In Bovine 6, a small area of thickening and little yellowish nodules with about $1 \mathrm{~mm}$ of diameter near to the thickening of the frontal cortex meninge were observed.

In the encephalon serial cut of Bovine 2 projections in the lateral ventricles were evidenced (Fig.1D), and creaked when cut. In the spinal cord ventral portion, irregular whitish areas of up to $5 \mathrm{~mm}$ were observed affecting the white and gray matter. In Bovine 3, multiple yellowish nodules of flat surface, with about $2 \mathrm{~mm}$ of diameter were noticed in the ventral cerebellar vermis, and the lateral ventricles were 
Table 1. Breed, sex, age, clinical signs and location of lesions in six cases of bovine tuberculosis with lesions in the nervous system

\begin{tabular}{|c|c|c|c|c|c|}
\hline Cattle & Breed & Sex & Age & Clinical signs & Location of lesions \\
\hline 1 & Red Sindhi & Male & Adult & $\begin{array}{l}\text { Cough, exercise intolerance, weight loss and } \\
\text { lymphadenomegaly }\end{array}$ & $\begin{array}{l}\text { Central nervous system (CNS), lung and } \\
\text { mediastinal lymph nodes }\end{array}$ \\
\hline 2 & $\begin{array}{l}\text { Brown } \\
\text { Swiss }\end{array}$ & Male & One year & $\begin{array}{l}\text { Incoordination, weakness, decreased } \\
\text { sensitivity of the pelvic limbs, sitting dog } \\
\text { posture and urinary incontinence }\end{array}$ & Lung and mediastinal lymph nodes, kidney \\
\hline 3 & $\begin{array}{l}\text { Crossbred } \\
\text { Holstein }\end{array}$ & Female & Nine years & $\begin{array}{l}\text { No clinical signs. Euthanized because } \\
\text { brucellosis test was positive }\end{array}$ & CNS \\
\hline 4 & Crossbred & Female & Two years & $\begin{array}{l}\text { Loss of balance, discrete mandibular trismus, } \\
\text { nystagmus, circling and falls }\end{array}$ & CNS, lung, liver \\
\hline 5 & Girolando & Female & Six months & $\begin{array}{l}\text { Lateral recumbence, opisthotonus, nystagmus, } \\
\text { medial strabismus, reduced facial sensitivity } \\
\text { and tetraparesis }\end{array}$ & CNS, lung and mediastinal lymph nodes \\
\hline 6 & $\begin{array}{l}\text { Crossbred } \\
\text { Holstein }\end{array}$ & Female & Eight years & $\begin{array}{l}\text { Weight loss, severe dyspnea, blindness with } \\
\text { corneal opacity of the left eye }\end{array}$ & $\begin{array}{l}\text { CNS, lung, mediastinal mesenteric and } \\
\text { intramammary lymph nodes, kidney, liver, } \\
\text { eyeball, diaphragm, spleen, mammary gland, } \\
\text { uterus and heart }\end{array}$ \\
\hline
\end{tabular}
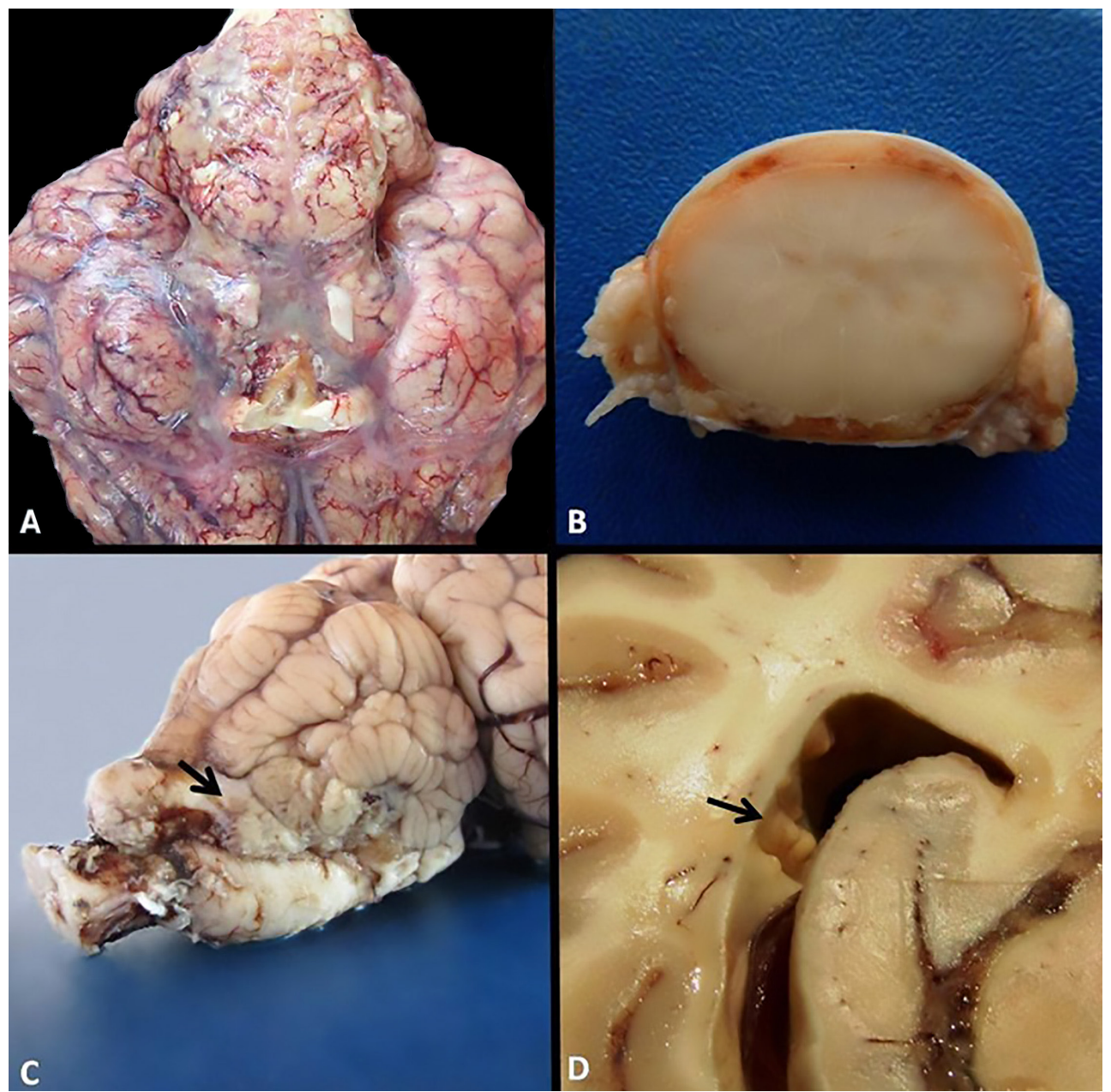

Fig.1. Tuberculosis in the central nervous system of bovine. (A) Encephalon of Bovine 2 presenting leptomeninges thickening in the basilar region. (B) Cervical spinal cord of Bovine 5 with thickening of the meninges. (C) Encephalon of Bovine 4 with cerebellar herniation and presence of a protruding mass in the cerebellum base (arrow). (D) Encephalon cut of Bovine 2 evidencing projections on the left lateral ventriculus wall (arrow). 
dilated. In Bovine 4, besides the mass in the fourth ventricle, it presented dilatation of the mesencephalic aqueduct, third ventricle, and lateral ventricles. The gray matter adjacent to the cortex meninge thickening of Bovine 6 presented areas of malacia with softening and granular appearance.

Besides the CNS lesions, yellow-whitish, soft, well delimited nodulations that presented resistance to the cut and contained caseous material with mineralized center were observed in the lungs of all bovines, except Bovine 3. In Bovines 1, 2, 5 and 6, the mediastinal lymph nodes presented enlarged with nodulations similar to the visualized in the lungs. Multiple whitish nodules were also seen in the kidneys of Bovine 1 and 6 , and in the liver of Bovine 4 and 6 . Bovine 6 presented similar formations in the left ocular globe, mesenteric and intramammary lymph nodes, diaphragm, spleen, mammary gland, uterine horns, and pericardial sac. Yellowish nodulations and abundant amounts of fibrin were observed between the pericardium and the epicardium.

Microscopically, leptomeninges thickening was observed in all bovines (Fig.2A), except in Bovine 4. The degree of

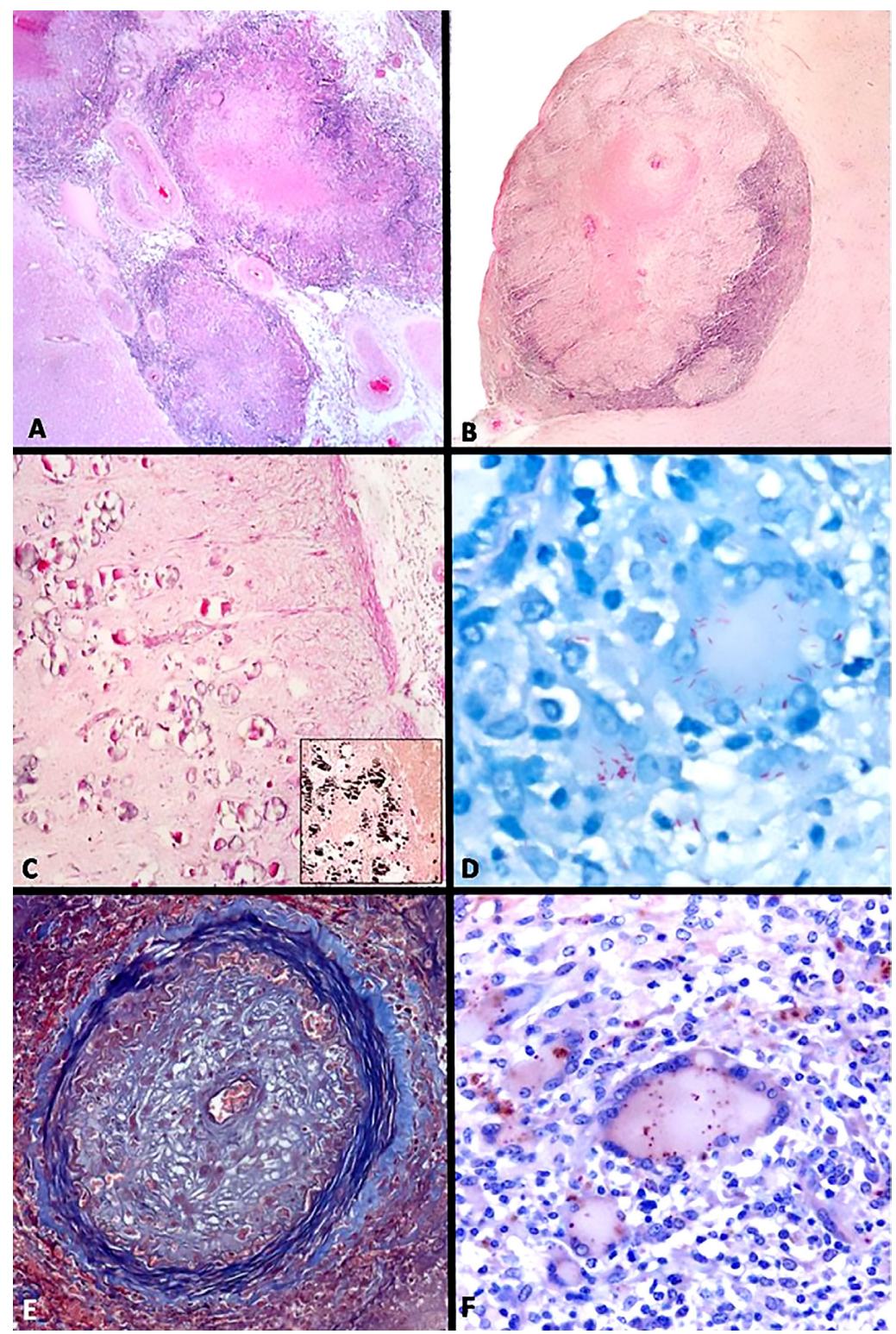

Fig.2. Tuberculosis in the central nervous system of bovine. (A) Cerebellar peduncle of Bovine 4. Thickening of the leptomeninges by multiple granulomas with central necrotic areas is observed. (B) Frontal cortex of Bovine 2 with meningeal granuloma compressing the adjacent neuropil. HE, obj.5x. (C) Pons of Bovine 2. Mineralization of the nervous tissue is observed. HE, obj.10x. In detail, Von Kossa stain demonstrating the mineralized areas in blackened tone. (D) Cerebral cortex of Bovine 5. Strong, intracytoplasmic alcohol-acid rods are observed in multinucleated giant cell of the Langerhans type and macrophages in the middle of the lesion. Ziehl-Neelsen, obj.100x. (E) Cerebral cortex of Bovine 6. Meningeal blood vessel evidencing tunica intima sharply proliferated in blue tone and with reduction in the lumen diameter. Masson's Trichome, obj.20x. (F) Cerebral cortex of Bovine 4. Positive immunostaining with anti-Mycobacterium tuberculosis is observed in the cytoplasm of epithelioid macrophages and multinucleated giant cells. Immuno-histochemical anti-M. tuberculosis, chromogen DAB, obj.40x. 
thickened varied from moderate, in Bovines 1 and 3 , to accentuated in Bovines 2, 5 and 6. The most affected regions were the cortex (all animals), colliculi, cerebellum, pons, obex (Bovine 1, 2, 3 and 5), and spinal cord (Bovine 2 and 5). This thickening was characterized by multiple granulomas with eosinophilic central areas of necrosis surrounded by mononuclear inflammatory infiltrate composed by lymphocytes, epithelioid macrophages, and giant multinucleated Langerhans cells associated to the slight proliferation of fibrous connective tissue (Fig.2B). In Bovines 2, 3 and 4, some granulomas presented mineralization in the necrotic central region. The granulomatous formation was accentuated around the blood vessels, resulting in the tunica intima thickening, with the presence of up to five layers of spindle cells with cytoplasm, and large and elongated nucleus. In some areas, the blood vessels observed in the middle of the inflammation presented eosinophilic walls with homogeneous and hyaline material deposition, similar to fibrinoid necrosis.

There was mild (Bovine 1, 3, 4 and 6) to moderate (Bovine 2 and 5) encephalitis, characterized by lymphocytic vasculitis in the neuropil adjacent to the granulomas. Furthermore, in Bovine 1, 2, 3 and 5 the leptomeninges of cortices, cerebellum, and cerebellar peduncle granulomas compressed the adjacent neuropil and in Bovine 5 were associated with vacuolization and axonal spheroids. The leptomeninges granulomas infiltrated the cortical neuropil of Bovine 6, which presented extensive area of malacia. In the spinal cord of Bovine 2, axonal spheroids and vacuoles of different sizes, sometimes containing Gitter cells ("digestion chambers"), were observed in the white matter. In this same animal there was granular material deposition foci, amorphous, strongly basophilic, identified as mineralization, in the granulous layer of the cerebellum and in the neuropil of the pons ventral region (Fig.2C).

Bovine 4 presented the same pattern of granulomatous inflammation around the vessels, however, the external layer of the granulomas had higher quantity of giant multinucleated cells and fibrous tissue in and around the inflammation. The inflammatory cells infiltrated the cerebellum and the cerebellar lateral peduncle provoking destruction of the adjacent tissue.

In other organs (lungs, liver, kidney, lymph nodes, spleen, peritoneum, uterus, and mammary gland) multifocal granulomatous areas were observed, composed by lymphocytes, macrophages and Langerhans giant multinucleated cells, with necrotic center, sometimes mineralized, and surrounded by a fibrous thick capsule. In the ocular globe, the granulomas invaded the uvea and occupied all anterior and posterior chambers. The uterus granulomas affected only the mucosa and there was mineralization of the muscle layer of the mucosa and submucosa vases.

In the Ziehl-Neelsen stain was evidenced few (Bovine 2 and 3 ) to numerous (Bovine 1, 4, 5 and 6) fine structures shaped like rods, reddish colored, localized in the macrophage's cytoplasm and Langerhans' multinucleated giant cells, and free in the granuloma (Fig.2D). With Masson's trichrome stain mild proliferation of collagenous was observed not only surrounding the granulomas, but also entering the lesion and interweaving the inflammatory cells. The wall of the blood vessels present in the middle and around the granulomas were thickened in up to seven times (Fig.2E). In the Von Kossa stain, mineralization was evidenced in the neuropil of Bovine 2 and in the middle of some granulomas of the leptomeninges of Bovines 2, 3 and 4 .

In all bovines there was positive stain in the CNS by immuno-histochemical technique using the polyclonal antibody anti-Mycobacterium tuberculosis. The immunostaining was observed, predominantly, in the macrophages' cytoplasm and multinucleated giant cells; rarely free in the granulomatous lesions (Fig.2F). The bacillus disclosure in the immuno-histochemical technique varied from accentuated in Bovine 1, 2 and 4, moderated in Bovine 3 and 6, and mild in Bovine 5.

\section{DISCUSSION}

By this study's results, it is verified that tuberculosis of the central nervous system affects bovines of different breeds and ages, with variable intensity and extension. It matches with variable neurological clinical signs according to the lesion location; some animals may present other clinical signs associated to pulmonary lesions or disseminated lesions, or not even evidence any clinical sign, as occurred in one of the cases of this study. Consequently to this variation in the clinical signs, the diagnosis of encephalic tuberculosis must be based in the macroscopic and histopathological alterations, and be confirmed by the immuno-histochemical or agent isolation.

The tuberculin test performed in two of the six cases allowed the previous diagnosis of only one animal, implicating in its euthanasia. The negative reaction to the tuberculin test can occur in cases of recent infection or in very chronic cases, as for the performance of the test in the same animal with intervals shorter than 60 days; in these cases, other auxiliary tests are necessary (Tizard 2014). In spite the negative result observed in an animal, the observation that four bovines presented exclusively nervous signs, suggests that the tuberculin test may be useful as differential diagnosis of the diseases that cause nervous signs in bovines of several ages.

Only one from the six animals with central nervous system tuberculosis tested positively to the tuberculin test. Other bovines that were diagnosed in the routine of the Veterinary Hospital of the UFCG did not go through the tuberculin test, hence, they were not identified with tuberculosis by the Brucellosis and Tuberculosis Control and Eradication National Program. The frequency of animals with central nervous system tuberculosis ( $8.2 \%$ of the bovine with tuberculosis), as for the high frequency of the several forms of the disease $(8.58 \%$ from the total of the cases received in LPV-UFCG) suggests that tuberculosis has high prevalence in dairy cattle in Paraíba and that efficient measures must be taken to control it.

In this study, the age of the six bovines with CNS tuberculosis was equal or superior to 12-months-old, differing from what is mentioned in the literature, which describes higher frequency of central nervous system tuberculosis in bovines with age under 12 months (Konradt et al. 2016), which is associated to transplacental infection, in animals born from cows with uterine tuberculosis, or through ingestion of milk from cows with lesions in the mammary gland (Roxo 1997, Oruç 2005, Riet-Correa \& Garcia 2007, Del Fava et al. 2010, Borges et al. 2013, Domingo et al. 2014). On the other hand, in this study the cases occurred primarily in adult animals most with pulmonary or generalized lesions, suggesting that the infection in the CNS occurred by dissemination of the primary pulmonary lesion. After invading the organism, 
Mycobacterium spp. infects macrophages that will circulate in the blood flow and reach several organs, as liver, lymph nodes, kidneys, spleen, uterus, mammary gland, eye and the CNS (Coutinho \& Tarragô 1976, Oruç 2005, Del Fava et al. 2010, Domingo et al. 2014, Tizard 2014). In the CNS the agent is also capable to infect microglia cells (Rock et al. 2008).

The location of the lesions, preferably in the meninges of the encephalon basilar region, and the anatomical characteristics of the blood perfusion in the CNS suggest that the bacteria get in the nervous system through the Willis' circle vessels; in this structure there is concentration of the blood for initial distribution of the encephalic arterial blood, besides the alteration in the local blood flow (Oruç 2005, Rock et al. 2008, Dyce et al. 2010, Konradt et al. 2016).

The mechanisms determining the location of tuberculosis lesions in the different regions of the CNS are not known, however, three well-defined forms of presentation in humans are known: meningeal thickening, miliary distribution, and unique tuberculous formation (Coutinho \& Tarragô 1976). Among the tuberculosis lesions observed in this report, the meningeal thickening was the most frequent, seen in five of the six cases studied in this study. The formation of a unique mass, observed only in one case (Bovine 4), occurs eventually (Konradt et al. 2016).

The fibrous tissue that covered the granulomas in the CNS, evidenced by the Masson's trichrome technique, was scarce, differing from the fibrosis observed commonly in other organs affected by the agent.. This fibrosis pattern, reported previously in the literature, maintains the inflammatory cells free and facilitates the infiltration of the tissues adjacent to the lesion (Andreazza et al. 2015).

The divergency in nervous clinical signs among the cases occurred possibly because of the different lesion intensity in the neuropil and its location (Coutinho \& Tarragô 1976, Oruç 2005, Riet-Correa et al. 2002, Del Fava et al. 2010, Konradt et al. 2016), The chronicity may have influenced in the degree of the CNS lesion (Rock et al. 2008), since Bovines 1,3 and 6 that presented granulomatous meningitis and compressive lesions, without significant alterations of the adjacent nervous tissue, did not show neurological clinical disturbances; while the bovines with diffuse and accentuated lesions in the meninges and brain tissues (Bovines 2, 4 and 5) presented nervous signs.

In the only case that the liquor was examined, lymphocytosis was confirmed, suggesting that the routine use of this technique, associated to the Ziehl-Neelsen stain, or to the isolation or molecular identification of the agent, may help in the diagnosis of the nervous form of tuberculosis. Humans with encephalic tuberculosis may present high lymphocyte cellular population in the liquor cytology; however, in the cases in which the infection is in the initial phase, neutrophils in greater quantity may be visualized (Coutinho \& Tarragô 1976, Rock et al. 2008). Besides the evaluation of the inflammatory cells present in the liquor, the Ziehl-Neelsen technique can be performed to observe the agent in the cerebrospinal fluid, though the absence of bacillus does not imply in the exclusion of the disease (Wilkins et al. 1986).

The mineralization observed in the neuropil of the pons and cerebellum of Bovine 2 in areas where there were not granulomas may have occurred initially as a metastatic calcification of the blood vessels and latter expanding to the tissue, as it is observed in some chronic diseases, as tuberculosis and paratuberculosis (Zachary 2013). The same process may have developed the mineralization in the uterine vessels of Bovine 6.

The severe histologic lesions in the tunica intima of the meningeal vessels, described before in human encephalic tuberculosis cases (Coutinho \& Tarragô 1976), suggest the invasion of the agent in the CNS through the hematogenous way. In humans, through angiographies, it is possible to identify tortuosity and aneurisms provoked by vascular compression, vasculitis and/or proliferation of the tunica intima of the blood vessels (Coutinho \& Tarragô 1976). The meningeal vessels are, therefore, the first affected by the inflammation, and the proliferation of the tunica intima may provoke complete occlusion of the vascular lumen, causing encephalic infarcts (Oruç 2005, Zachary 2013).

\section{CONCLUSIONS}

The tuberculosis in the central nervous system in bovine of Paraíba affects young and old bovines, of different breeds, with different clinical signs.

The different ages in the affected bovines, the vascular lesions, and the presence of lesions in other organs, suggest that the infection occurs by dissemination from other organs by the hematogenous way.

The high relative frequency of tuberculosis in Paraíba (8.58\% of all diagnosed cases in bovines) and the high frequency of cases with lesions in the nervous system $(8.2 \%$ of all tuberculosis cases) indicate that encephalic tuberculosis must be included in the differential diagnosis of other diseases affecting the CNS in cattle in the state.

\section{REFERENCES}

Andreazza D., Boos G.S., Boabaid F.M., Wouters A.T.B., Wouters F., Souza S.O., Menegat M.B. \& Driemeier D. 2015. Caracterização histologica e imuno-histoquímica das lesões de tuberculose em bovinos e de linfadenitegranulomatosa em suínos. Pesq. Vet. Bras. 35(2):129-136. <http://dx.doi.org/10.1590/S0100-736X2015000200006>

Borges P.C., Nakagaki K.Y.R., Lopes P.R.F., Souza B., Utiumi K. \& Raymundo D.L. 2013. Tuberculose meningeana e na forma de tubérculos isolados no sistema nervoso central de uma novilha holandesa. Arch. Vet. Sci. 12(2):185-187.

Coutinho L.M.B. \& Tarragô R.P. 1976. Tuberculose meningoencefálica na infância: estudo anatomo-patológico de 10 casos. Arq. Neuropsiquiatr. 34(2):127-134. <http://dx.doi.org/10.1590/S0004-282X1976000200003> $<$ PMid:1084147>

Del Fava C., Roxo E., Baldassi L., Cunha E.M.S. \& Cabral A.D. 2010. Granulomatous meningo myeloencephalitis in a calf caused by Mycobacterium bovis. Arqs Inst. Biológico, São Paulo, 77(2):335-338.

Domingo M., Vidal E. \& Marco A. 2014. Pathology of bovine tuberculosis. Res. Vet. Sci. 97(Suppl.):20-29. <http://dx.doi.org/10.1016/j.rvsc.2014.03.017> <PMid:24731532>

Dyce K.M., Sack W.O. \& Wensing C.J.G. 2010. 0 sistema nervoso, p.268-331. In: Ibid. (Eds), Tratado de Anatomia Veterinária. 4⿳⺈ e ed. Elsevier, Rio de Janeiro.

Galiza G.J.N., Silva M.L.C.R., Dantas A.F.M., Simões S.V.D. \& Riet-Correa F 2010. Doenças do sistema nervoso de bovinos no semiárido nordestino. Pesq. Vet. Bras. 30(3):267-276. <http://dx.doi.org/10.1590/S0100736X2010000300014>

Konradt G., Bassuino D.M., Bianchi M.V., Bandinelli M.B., Driemeier D. \& Pavarini S.P. 2016. Neurotuberculosis in cattle in southern Brazil. Trop. Anim. Health Prod. 48(5):1089-1094.<http://dx.doi.org/10.1007/s11250016-1048-Z><PMid:27026233>

Oruç E. 2005. Meningoencephalitis tuberculosa in a holstein cow. Vet. Pathol. 42(6):856-858. <http://dx.doi.org/10.1354/vp.42-6-856><PMid:16301587> 
Riet-Correa F. \& Garcia M. 2007. Tuberculose, p.432-442. In: Riet-Correa F, Schild A.L., Lemos R.A.A. \& Borges J.R.J. (Eds), Doenças de Ruminantes e Equídeos. Vol.1. 3aㅡ ed. Pallotti, Santa Maria.

Riet-Correa F., Riet-Correa G. \& Schild A.L. 2002. Importância do exame clinico para o diagnóstico das enfermidades do sistema nervoso em ruminantes e eqüídeos. Pesq. Vet. Bras. 22(4):161-168. <http://dx.doi.org/10.1590/ S0100-736X2002000400006>

Rock R.B., Olin M., Baker C.A., Molitor T.W. \& Peterson P.K. 2008. Central nervous system tuberculosis: pathogenesis and clinical aspects. Clin. Microbiol. Rev. 21(2):243-261. <http://dx.doi.org/10.1128/CMR.0004207><PMid:18400795>
Roxo E. 1997. Mycobacterium bovis como causa de zoonose. Revta Bras. Ciênc. Farm. 18(1):101-108.

Tizard I.R. 2014. Hipersensibilidade do tipo IV: hipersensibilidade tardia, p.365-375. In: Ibid. (Eds), Imunologia Veterinária. 9aa ed. Elsevier, Rio de Janeiro.

Wilkins E.G.L., Griffiths R.J., Roberts C. \& Green H.T. 1986. Tuberculous meningitis due to Mycobaterium bovis: a report of two cases. Postgrad. Med. J. 62(729):653-655. <http://dx.doi.org/10.1136/pgmj.62.729.653> <PMid:3529067>

Zachary J.F. 2013. Sistema nervoso, p.803-804. In: Zachary J.F. \& McGavin M.D. (Eds) Bases da Patologia em Veterinária. 5a ed. Elsevier, Rio de Janeiro. 